\title{
Testing The Role Of Country Of Origin, Celebrity Endorser, Ads And E-Wom Towards Consumer Buying Interest
}

\author{
Amir Abdul Karim 1 ) \\ amir.cmx20@gmail.com \\ Budi Istiyanto2) \\ budisties@gmail.com \\ 1)2)Sekolah Tinggi Ilmu Ekonomi Surakarta
}

\begin{abstract}
This research is motivated by the increasing market share of OPPO Smartphones in Indonesia in the Second Quarter of 2019. It is thought that this increase has an effect on increasing sales of the OPPO Smartphone and also makes the reason OPPO Smartphones are able to overtake Samsung's position in Indonesia. The purpose of this study is to analyze the variables Country of Origin, Celebrity Endorser, Advertising and E-WOM on Purchase Interest of OPPO Smartphone products. The research method used is quantitative research. Determination of the number of samples using non-probability sampling techniques with a purposive sampling method with a total sample of 126 respondents. This study uses multiple linear regression analysis. The results of the study indicate that the Country of Origin, Advertisements and E-WOM variables have a positive and significant effect on buying interest in OPPO Smartphone products. While the Celebrity Endorser variable does not significantly influence the buying interest of OPPO Smartphone products.
\end{abstract}

Keywords: Country of Origin, Celebrity Endorser, Advertising, E-WOM and Purchase Interest 


\section{PRELIMINARY}

The rapid development of the era of globalization is something that cannot be avoided. Conversations between individuals today need to be considered because developing telecommunications is also a trigger for producers competing in making the most up-to-date communication tools. One of the communication technology which has a very rapid development nowadays is the Cellphone or often called Smartphone. This development comes from various vendors that produce Smartphones, while these vendors compete with each other to be able to control the market both locally and globally.

In 2019, OPPO corrected a surprising increase, in Indonesia itself OPPO was able to win the Smartphone market in the second quarter of 2019. Canalys research institute, said that the Smartphone market in Indonesia showed good results in the April to June 2019 period. Smartphone shipments to Indonesia in the second quarter of 2019 were able to penetrate the 11.4 million units, or grew 8.9 percent YoY. The data also states that for the first time where Samsung, which has long won the Smartphone market, was able to be overtaken by OPPO vendors in the Indonesian smartphone market in the second quarter of 2019. Citing Canalys data, Canalys mentioned, in the second quarter of 2019, OPPO could support the Smartphone market in Indonesia with a market share of $26 \%$ or growing $54 \%$ YoY, followed by Samsung with a market share of $24 \%$, or growing $10 \%$ YoY.

\section{Table 1.}

Indonesian Five Top Smartphone Vendor in Q2 2019

\begin{tabular}{llll}
\hline & Vendor & Unit Share & YoY Growth \\
$\# 1$ & OPPO & $26 \%$ & $+54 \%$ \\
$\# 2$ & SAMSUNG & $24 \%$ & $+10 \%$ \\
$\# 3$ & XIAOMI & $19 \%$ & $-9 \%$ \\
$\# 4$ & VIVO & $15 \%$ & $+62 \%$ \\
$\# 5$ & REALME & $7 \%$ & N/A \\
\hline
\end{tabular}

From: https://tekno.kompas.com/ 


\section{RESEARCH FRAMEWORK AND HYPOTHESES}

\section{Country of Origin}

In evaluating products, consumers not only consider their attractiveness and physical specifications, but also consider the State that produces them. (Tjiptono: 2008). Gumelar and Sopiyan (2019) state that Country of Origin assists consumers in assessing a product for decision making and as a general description of a product that might affect consumer behavior.

Celebrity Endorser

Blech and Blech (2009) Defining Celebrity Endorser as a support in advertising which is the main source directly in delivering messages or demonstrating the products or services of these advertisements. According to Iwan and Nainggolan (2017) using Endorser in advertising is intended to be a spokesperson in advertisements so that the brand or brand of the product can more quickly get a position in the minds of consumers, until the emergence of a desire to buy a product.

Advertisement

Kotler \& Keller (2012) defines advertising as any form of presentation and promotion of ideas for goods and services that are carried out by certain sponsors on a non-personal and paid basis. Sudirjo and Handoyo (2018) state that the image of products and sales is built through long-term advertising. Mahmudah \& Sutrisna (2018) explained that advertising is to introduce a product and provide information of product advantages through various media such as electronic media, magazines, or billboards to introduce products to consumers.

\section{E-WOM}

Thurau, et al., (2004) explained that the Internet is a medium for potential customers or former customers to convey positive and negative experiences to the product. Cahyono, et al (2016) Social media is allegedly more effective in implementing E-WOM because it can be touched by the wider community. Through E-WOM on social media, businesses benefit more because of the low cost but high impact of the process. Purchase Interest 
According to Hasan (2013) Buying Interest is an action taken by consumers related to purchasing behavior as measured by the level of consumers making a purchase. Iwan and Nainggolan (2017) stated that buying interest is a perception formed through the learning process and thought process. Interest in buying creates an impulse that is able to be recorded in one's mind and becomes a very strong desire, finally when the consumer must meet his needs will actualize what is in his mind.

Framework for Thinking

\section{Figure 1:}

Framework for Thinking

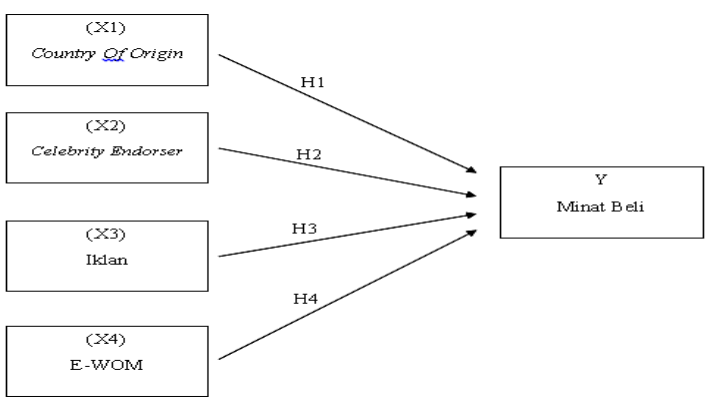

From: though personal data

Hypothesis

Based on the theory and framework of thinking a hypothesis can be formulated as follows:

a. It is suspected that Country of Origin influences buying interest

b. Allegedly Celebrity Endorser influence buying interest

c. It is suspected that advertising influences buying interest

d. It is suspected that E-WOM has an influence on buying interest

\section{RESEARCH METHODS}

This research used a quantitative method. The study was conducted in Solo City with its population being the people of Solo City who used Smartphones. Sample calculation that has been done by the sample researchers is 126 samples. Tests using multiple linear regression analysis with the IBM SPSS 20 program. 


\section{RESEARCH RESULTS AND DISCUSSION}

Research result

a. Test Instrument Data

The validity test results indicate that all statement items in this study are valid because $r$ count $>\mathrm{r}$ table $(0.1750)$. While the reliability test results show reliable results with Cronbach alpha values of each variable> 0.6.

b. Classic assumption test

Classic assumption tests include multicollinearity, heteroscedasticity and normality tests. In the multicollinearity test results showed that the regression model in the study did not occur multicollinearity because the VIF value $<10$ and tolerance value $\geq 0.10$. Heteroscedasticity test uses Rank Spearman's rho method, of all the independent variables stated heteroscedasticity did not occur because of the value of sig. $>0.05$. As well as the normality test, the results show that the value of the kormogolov-smirnov test results $>0.05$, then the model is declared normal.

c. Multiple Linear Regression Analysis

To examine the role of country of origin, celebrity endorser, adverts and e-wom on the buying interest of oppo smartphone products in Solo, a multiple linear regression analysis was used.

Table 2.

The results of multiple linear regression analysis test

\begin{tabular}{lccccc}
\hline \multirow{2}{*}{ Variabel } & $\begin{array}{c}\text { Unstandarized } \\
\text { Coefficients }\end{array}$ & & $\begin{array}{c}\text { Standardized } \\
\text { Coefficients }\end{array}$ & & \\
\cline { 2 - 4 } & B & Std. & Beta & & Sig. \\
\cline { 2 - 4 } & 2.927 & 2.388 & & 1.226 & .223 \\
Konstanta & 0.371 & 0.102 & 0.255 & 3.633 & .000 \\
Country of Origin & 0.137 & 0.094 & 0.115 & 1.445 & .151 \\
Celebrity Endorser & 0.280 & 0.094 & 0.282 & 2.995 & .003 \\
Iklan & 0.342 & 0.109 & 0.273 & 3.139 & .002 \\
E-WOM & & & & & \\
\hline
\end{tabular}

From: though personal data

Test results, obtained the following equation:

$$
Y=2,927+0,371 X_{1}+0,137 X_{2}+0,280 X_{3}+0,342 X_{4}+e
$$


The constant value of 2.927 shows that although the Country of Origin, Celebrity Endorser, Advertising, and E-WOM variables are considered constant or zero (0), the value of buying interest on OPPO Smartphone products is 2.927. Country of Origin regression coefficient value of 0.371 and marked $(+)$ means that if the value of Country of Origin increases, it will contribute 0.371 to the increase in the value of Purchase Interest. The Celebrity Endorser regression coefficient value of 0.137 and marked $(+)$ means that if the value of the Celebrity Endorser variable increases, it will contribute 0.137 to the increase in the value of Purchase Interest. Ad regression coefficient value of 0.280 and marked $(+)$ means that if the value of the Ad increases, it will contribute 0.280 to the increase in the value of Purchase Interest. E-WOM regression coefficient value of 0.342 and marked $(+)$ means that if the value of the E-WOM variable increases, it will contribute 0.342 to the increase in the value of Purchase Interest.

d. T test

Test results partially show Country of Origin, Advertising, and E-WOM have a significant effect on buying interest, indicated by tcount $>$ ttable $(1,979)$ and a significance level < of 0.05. While Celebrity Endorser did not have a significant effect on buying interest, it was shown tcount $<$ t table $(1,979)$ and significance level $>0.05$.

e. Coefficient of determination (R2)

The test results show the value of Adjusted $\mathrm{R}$ Square is 0.575 . Based on these results it is explained that (Country of Origin, Celebrity Endorser, Advertising, and E-WOM) affect Purchase Interest on OPPO Smartphones in Solo City by $57.5 \%$ and $42.5 \%$ explained by factors outside the model.

\section{DISCUSSION}

The results showed the Country of Origin variable had a positive and significant effect on consumer buying interest. This proves that country believe with the statement about the State of China (China) is an innovative smartphone producing country in the field of manufacturing and also has a high level of technology can provide positive perceptions to consumers so that it can contribute to increasing consumer buying interest towards OPPO Smartphone products in Solo City . Furthermore, the consumer persession with the Desired Interaction indicator by stating that the State of China 
(China) has a good cooperative relationship with Indonesia in various fields can also give a positive value to the country's image. This can affect consumer buying interest. People affect indicators that can also provide a perception of a country that is related to human resources that are innovative, creative and have high competitiveness can provide consumers' perceptions about the country, so that it will also contribute to increasing consumer buying interest. The results of this study are in accordance with Syaquina, et al (2017), Yanthi and Jatra (2015).

Celebrity Endorser has no significant effect on consumer buying interest. This means that with the presence or absence of Celebrity Endorser both in terms of popolarity, ability, attractiveness and strength of the celebrity can not make a major contribution to increasing consumer buying interest. This is not in accordance with the research of Iwan and Nainggolan (2017), Pratiwi and Moeliono (2015). Advertising has a positive and significant influence on buying interest. It is shown from several indicators, the first is interest in advertising on television and social media can attract consumers. Furthermore, consumers assume that attention, desire and action are in the next level in advertising to influence consumer buying interest. These results are consistent with the research of Putra, Algamar (2017), Safriadi and Hardyaningwati (2017).

E-WOM has a positive and significant influence on consumer buying interest. It is shown by Intensity that the frequent display of OPPO Smartphone advertisements on social media is able to provide a positive value on consumers' perceptions in influencing buying interest in OPPO Smartphone products. Then followed by Content, if the content in the social media post is interesting and provides clear information then it will also be able to contribute to increasing interest from consumers to buy products, as well as Valence of opinion, namely positive comments on OPPO Smartphone products in OPPO Smartphone social media that also increase the level of consumer buying interest. The results of this study are in accordance with the research of Laksmi and Oktavani (2016), Naufal and Sari (2017). 


\section{CONCLUSION}

Based on the test results in the study and the discussion that has been presented by researchers, it was concluded: Country of Origin, Advertisements, and E-WOM have a positive and significant effect on consumer buying interest in OPPO Smartphone products. Celebrity Endorser has no significant effect on consumer buying interest on OPPO Smartphone products.

This research is limited to the Solo City area, which is certainly not able to provide a picture of consumer interest in OPPO Smartphone products in Indonesia. It is hoped that further research can be carried out in other regions that are able to explain the description of consumers' buying interest in OPPO Smartphone products, for example in the regions of Kalimantan, Sulawesi, Sumatra and other regions in Indonesia. This research is limited to only a few variables namely Country of Origin, Celebrity Endorser, advertising and E-WOM. It is expected that in future studies to be able to use other variables such as packaging design, availability of goods, discounts and others.

\section{REFERENCE}

Belch, George E., dan Michael A. Belch, (2007), Advertising and Promotion: An Integrated Marketing Communication Perspective, 8th edition, McGraw-Hill, Irwin, Boston Cahyono, Firman Dwi; Andriani Kusumawati dan Srikandi Kumadji, (2016), Analisis Faktor-Faktor Pembentuk Electronic Word-Of-Mouth (Ewom) Dan Pengaruhnya Terhadap Minat Beli (Survei Pada Followers Akun Instagram @Saboten_Shokudo) Jurnal Administrasi Bisnis (JAB), Vol. 37 No.

Hasan, Ali, (2013), Marketing dan Kasus-Kasus Pilihan (1). Yogyakarta, CAPS

Iwan dan Kaman Nainggolan, (2017), Pengaruh Celebrity Endorser, Brand Awareness Dan Harga Produk Terhadap Minat Beli Mie Suksess (Studi Empiris Pada Penduduk Kecamatan Pinang-Kota Tangerang), Cakrawala, Vol. XVII, No. 2 Kotler \& Keller (2012), Manajemen Pemasaran, edisi 14, Jakarta, Erlangga Laksmi, Aditya Ayu dan Farah Oktafani, (2016), Pengaruh Electronic Word Of Mouth (EWOM) Terhadap Minat Beli Followers Instagram Pada Warunk Upnormal, Jurnal Computech \& Bisnis, Vol. 10 No. 2 
Naufal ,Ahmad dan Devilia Sari, (2017) Pengaruh Electronic Word of Mouth (e-WOM)

Terhadap Minat Beli Buldalk Bokkeummyeon (samyang) pada masyarakat di Kota Bandung, e-Proceeding of Management, Vol.4, No.3

Pratiwi, Indri dan Nadya Moeliono, (2015), Pengaruh Celebrity Endorser Maudy Ayunda Terhadap Minat Beli Produk Teh Javana (Studi Pada Masyarakat Di Kota Bandung), e-Proceeding of Management, Vol.2, No.3

Putra, Algamar, (2017), Pengaruh Iklan Dan Kepercayaan Merek Terhadap Minat Beli Konsumen (Studi Pada Texas Chicken Pekanbaru), JOM FISIP, Vol. 4 No. 1

Safriadi dan Hardyaningwati, (2017), Pengaruh Atribut Produk Dan Iklan Terhadap Minat Beli Kendaraan Bermotor Jenis Metic Merek Honda Pada Pt. Astra Honda Motor Jakarta Timur, Jurnal IlmiahWIDYA, Volume 4 Nomor 1

Schiffman, L.G., dan Kanuk, L.L, (2007), Costumer Behaviour, Third Edition, Engelwood Cliffs, New Jersey, Prentice-hall Inc.

Sopiyan, Pipih dan Gun Gun Gumelar, (2019), Pengaruh Brand Equity Dan Country of Origin Terhadap Minat Beli Produk Smartphone Samsung (Studi Pada Mahasiswa Fakultas Ekonomi Universitas Majalengka), Jurnal Ilmiah Ekonomi dan Keuangan Syariah, Volume I, Nomor 1

Sudirjo, Frans dan Edi Anwar Handoyo, (2018), Pengaruh Kualitas Produk Dan Iklan Terhadap Minat Beli Konsumen AMDK Amidis Di Semarang, Serat Acitya Jurnal Ilmiah UNTAG Semarang, Vol. 7 No. 1

Syaquina, Sarah; Ratih Tresnati dan Septiana A Estri Mahani, (2017), Pengaruh Country of Origin Terhadap Minat Beli Sepeda Motor Tvs (Studi Survey Konsumen Sepeda Motor Kota Bandung), Prosiding Manajemen, Vol.3 No.2

Thurau, Hennig T.; Gwinner, K. P.; Walsh, G. and Gremler, D. D., (2004). Electronic word-of-mouth via consumer-opinion platforms: what motivates consumers to articulate themselves on the Internet?, Journal of Interactive Marketing. Vol. 18 No. 1

Tjiptono, Fandi, 2001, Strategi Pemasaran, Yogyakarta., Penerbit Andi

Yanthi, Kadek Pratita dan I Made Jatra, (2015), Pengaruh Country of Origin, Brand Image, Dan Perceived Quality Terhadap Minat Beli Sepeda Motor Honda Beat Di Kota Denpasar, E-Jurnal Manajemen Unud, Vol. 4, No. 11 
https://tekno.kompas.com/read/2019/08/13/10570037/salip-samsung-oppo-jadipabrikan-ponsel-nomor-satu-di-indonesia?page=all. 